\title{
A review of the Europe indicators on climate change - industry, innovation and infrastructure
}

\author{
Iudit Bere-Semeredi ${ }^{1}$, and Anca Mocan $^{1}$ \\ ${ }^{1}$ Politehnica University of Timisoara, Faculty of Management in Production and Transportation, \\ 14 Remus str., 300191 Timisoara, Romania
}

\begin{abstract}
The paper presents a study based on the European statistics available to characterize the Sustainable Development Goal 9 that calls for building resilient and sustainable infrastructure and promotes inclusive and sustainable industrialization. A debate on the achievements and the situation at the EU-28 level and comments on the Romania and the former Communist countries will be made based on the existing broad positions or discourses within the climate change: gradualism, skepticism and catastrophism. Conclusions and final debates are dedicated to the EU context development focuses on two main dimensions: research and development and innovation, and sustainable transport.
\end{abstract}

\section{Introduction}

The European Treaties strongly included and focus on sustainable development and different time visions, strategies have been at the heart of European policy for a long time. The "2030 Agenda for Sustainable Development" (2015), have given a new impetus to global efforts for achieving sustainable development. Since 2015, the United Nations (UN) General Assembly endorsed "Transforming Our World: the 2030 Agenda for Sustainable Development", a global development agenda for all countries and stakeholders to use as a blueprint for progress on economic, social, and environmental sustainability. Seventeen Sustainable Development Goals (SDGs) and associated Targets and Indicators anchor the 2030 Agenda, which specifically calls for new data acquisition and exploitation of a wide range of data sources to support implementation [1].

The EU is fully committed to the 2030 Agenda trying to proof progress towards the SDGs targets. Researchers also investigate different aspects and progresses trying to support thorough their scientifically based studies and analysis, the progresses of different industries, communities or policies of the Member States [2-4]. From the perspective of the policy makers the publications and reports of Eurostat's are of great importance, since they regular report the monitoring progress towards the SDGs [5-6].

The last analysis and the report publication in 2018 are based on the European Union SDG indicator set, and the study has been developed with the support of many stakeholders; the indicator set comprises 100 indicators and is structured along the 17 SDGs

* Corresponding author: iudit.bere-semeredi@student.upt.ro 
[6]. In addition, for each SDG, the last report focuses on aspects which are relevant for the European Member States perspective.

In the context of the present article there will be analysed the provide statistical data and information presented by [5] in order to underline some actual problems of climate change in Europe, by using a quantitative approach for characterizing the industry, innovation and infrastructure.

\section{Literature review}

\subsection{Climate change theories and implications at the European level}

From the scientific, practical and the policy makers point of views, there have been identified three broad positions or discourses within the climate change: gradualism, skepticism and catastrophism (see Table 1 for additional descriptions based on the literature review).

Table 1. The three approached of climate change (a synthesis from the literature).

\begin{tabular}{|c|c|c|}
\hline Approach & Description & References \\
\hline Gradualism & $\begin{array}{l}\text { Involves the claims that climates are changing around the } \\
\text { world, that human activities are significantly responsible for } \\
\text { these changes, that these changes are relatively slow, and that } \\
\text { economies need to be adjusted in order to reduce future } \\
\text { temperature increases. } \\
\text { It needs the development of new technologies that will } \\
\text { somehow fix the problem of climate change by introducing } \\
\text { new ways of generating energy. } \\
\text { The theory is supported by climate change science. }\end{array}$ & {$[6-11]$} \\
\hline Skepticism & $\begin{array}{l}\text { Involves challenging the sciences of climate change } \\
\text { especially considering the huge uncertainties involved in } \\
\text { predicting changes in temperatures over future decades. } \\
\text { It is argued that climates have altered in the past as a result of } \\
\text { natural processes such as sun spot activity rather than } \\
\text { processes which are anthropogenic. } \\
\text { Climate change science is combated in order to promote } \\
\text { business as usual. }\end{array}$ & {$[6-8,12]$} \\
\hline Catastrophism & $\begin{array}{l}\text { Draws upon historical, ice core and archaeological data to } \\
\text { maintain that positive feedbacks will take the climate system } \\
\text { away from equilibrium through positive feedback effects. } \\
\text { Many scientists also, generated the thesis that the earth is a } \\
\text { single complex system and can be subject to very rapid } \\
\text { system shifts moving abruptly across thresholds. } \\
\text { Climate change consequences will be catastrophic for human } \\
\text { life on earth. }\end{array}$ & {$[6-8,13]$} \\
\hline
\end{tabular}

According to the comparison research of climate change perceptions and practices in [6] it has been stated "that for Western European countries: citizens on the right are less likely than those on the left to believe that anthropogenic climate change is occurring, perceive climate change to be a serious problem, believe we should deal with climate change, express personal willingness to pay to deal with climate change, and support policies to reduce greenhouse gas emissions". Furthermore, there is a different ideology on issues of climate change in the former Communist countries from the Eastern Europe because 
environmental topics have been less salient political (lower levels of concerned). This has been also considered in the research of [14].

The extended analysis of [6] underlined that the "lack of a consistent ideological divide in the former Communist countries is likely due to the low political salience of climate change and the differing meaning of left-right identification in these countries".

Thus, the quantitative research of [6] has underlined a consistent ideological divide on climate change views in "Western European countries, where citizens on the right were less likely than those on the left were to believe that anthropogenic climate change is occurring, perceive climate change to be a serious problem, believe we should deal with climate change, express a personal willingness to pay to deal with climate change, and support policies to reduce greenhouse gas emissions". In contrast, such a divided ideology on climate change was not found among the general publics of former Communist countries, presumably for the reasons outlined above. For these statements and findings, it could be considered that the research of [6] reinforce those of [14], who conclude to similar issues on general environmental attitudes and perceptions, considering they are attributes that could be associated to the "post-Communist effect".

These brief debate on the climate change views in Europe have been recently proved by the results of the quantitative analysis of $[15,16]$. As a general conclusion, all Member States have common responsibilities when it comes to climate change, but the policymakers actions are different implemented. Thus, supported the idea that at the European level there is still a great "reserve of solutions and measures" for climate change mitigation.

\subsection{The industry, innovation and infrastructure challenges in the climate change context}

The idea behind this debate rises from the established goal of SDG: Goal 9 calls for building resilient and sustainable infrastructure and promotes inclusive and sustainable industrialization. It also recognizes the importance of research and innovation for finding lasting solutions to social, economic and environmental challenges [5-6]. Furthermore, the SDG 9 calls on Member States to build resilient infrastructure, promote inclusive and sustainable industrialization and foster innovation.

Economics practice has proofed that inclusive and sustainable industrial development is the primary source of income and support a rapid and sustained increases of life quality for all people. Furthermore, research and development (R\&D) and innovation drive economic growth, job creation, labour productivity and resource efficiency; they are considered important "engines" in the knowledge-based economy and have positive impact and support on European companies' competitiveness.

In the last years, there has been recognized that investments in sustainable and energy efficient transport and mobility systems are key elements for achieving sustainable development. Table 2 shows the taxonomy of the SDG nine goal's indicators according to the [5].

Table 2. The considered indicators for the SDGs nine goal [5].

\begin{tabular}{|c|l|}
\hline $\begin{array}{c}\text { Indicator of } \\
\text { SDGs nine goal }\end{array}$ & \multicolumn{1}{c|}{ Definition and explanations } \\
\hline \multicolumn{2}{|c|}{ R\&D and innovation section } \\
\hline $\begin{array}{c}\text { Gross domestic } \\
\text { expenditure on } \\
\text { R\&D }\end{array}$ & $\begin{array}{l}\text { This indicator measures gross domestic expenditure on R\&D (GERD) as a } \\
\text { percentage of the gross domestic product (GDP). The Frascati Manual defines } \\
\text { research and development (R\&D) as creative and systematic work undertaken } \\
\text { in order to increase the stock of knowledge - including knowledge of } \\
\text { humankind, culture and society - and to devise new applications of available } \\
\text { knowledge }\end{array}$ \\
\hline
\end{tabular}




\begin{tabular}{|c|c|}
\hline $\begin{array}{l}\text { Employment in } \\
\text { high- and } \\
\text { medium-high } \\
\text { technology } \\
\text { manufacturing } \\
\text { sectors and } \\
\text { knowledge- } \\
\text { intensive service } \\
\text { sectors }\end{array}$ & $\begin{array}{l}\text { The indicator measures the employment in high- and medium-high technology } \\
\text { manufacturing sectors and in knowledge-intensive service sectors as a share of } \\
\text { total employment. Data stem from the European Labour Force Survey (LFS). } \\
\text { The definition of high- and medium-high technology manufacturing sectors } \\
\text { and of knowledge intensive services is based on a selection of relevant items } \\
\text { of the Statistical classification of economic activities in the European } \\
\text { Community (NACE) Rev. } 2 \text { at 2-digit level and is oriented on the ratio of } \\
\text { highly qualified working in these areas. }\end{array}$ \\
\hline R\&D personnel & $\begin{array}{l}\text { This indicator measures the share of R\&D personnel broken down by the } \\
\text { following institutional sectors: business enterprise, government, higher } \\
\text { education and private non-profit. Data are presented in full-time equivalents as } \\
\text { a share of the economically active population (the labour force). }\end{array}$ \\
\hline $\begin{array}{l}\text { Patent } \\
\text { applications to } \\
\text { the European } \\
\text { Patent Office } \\
\quad \text { (EPO) }\end{array}$ & $\begin{array}{l}\text { This indicator measures the requests for protection of an invention directed } \\
\text { either directly to the European Patent Office (EPO) or filed under the Patent } \\
\text { Cooperation Treaty and designating to the EPO (Euro-PCT), regardless of } \\
\text { whether they are granted or not. } \\
\text { The data show the total number of applications per country. If one application } \\
\text { to the EPO has more than one inventor, the application is divided equally } \\
\text { among all of them and subsequently among their countries of residence, thus } \\
\text { avoiding double counting. Euro-PCT applications are allocated according to } \\
\text { the nationality of the first listed applicant. }\end{array}$ \\
\hline \multicolumn{2}{|r|}{ Sustainable transport } \\
\hline $\begin{array}{l}\text { Share of buses } \\
\text { and trains in } \\
\text { total passenger } \\
\text { transport }\end{array}$ & $\begin{array}{l}\text { This indicator measures the share of buses, including coaches and trolley- } \\
\text { buses, and trains in total passenger transport performance, expressed in } \\
\text { passenger kilometres (pkm). Total passenger transport here includes transport } \\
\text { by passenger cars, buses and coaches, and trains, and excludes air and sea } \\
\text { transport. All data should be based on movements within national territories, } \\
\text { regardless of the nationality of the vehicle. } \\
\text { The data collection is voluntary and not fully harmonized at the EU level. } \\
\text { Other collective transport modes, such as tram and metro systems, are not } \\
\text { included due to the lack of harmonized data. }\end{array}$ \\
\hline $\begin{array}{l}\text { Share of rail and } \\
\text { inland } \\
\text { waterways } \\
\text { activity in total } \\
\text { freight transport }\end{array}$ & $\begin{array}{l}\text { This indicator measures the share of rail and inland waterways in total inland } \\
\text { freight transport, expressed in tonne-kilometres (tkm). Inland freight transport } \\
\text { modes include road, rail and inland waterways. Rail and inland waterways } \\
\text { transport is based on movements on national territory, regardless of the } \\
\text { nationality of the train or vessel. Road transport is based on all movements of } \\
\text { vehicles registered in the reporting country. } \\
\text { The redistribution of road transport according to the 'territoriality principle' } \\
\text { involves modelling the likely journey itinerary and projecting it on to the } \\
\text { European road network. Neither sea nor air freight transport are represented in } \\
\text { the indicator. }\end{array}$ \\
\hline $\begin{array}{l}\text { Average } \mathrm{CO}_{2} \\
\text { emissions per } \\
\text { km from new } \\
\text { passenger cars }\end{array}$ & $\begin{array}{l}\text { The indicator is defined as the average carbon dioxide }\left(\mathrm{CO}_{2}\right) \text { emissions per km } \\
\text { by new passenger cars in a given year. The reported emissions are based on } \\
\text { type-approval and can deviate from the actual } \mathrm{CO}_{2} \text { emissions of new cars. } \\
\text { Data presented in this section are provided by the European Commission, the } \\
\text { Directorate-General for Climate Action and the Environmental European } \\
\text { Agency (EEA). }\end{array}$ \\
\hline
\end{tabular}

These indicators will be analysed in the next section of this article with the purpose of demonstrating the statement of $[6,14]$ on the different discrepancies of the West European countries developments and policies and the Eastern one. 


\section{Materials and method}

The review study is based on the Eurostat statistics available for the category "Environment" that have been refine only for the subcategory of "climate change". The study is focused on the SGDs methodology and the related 17 topics or themes established by the United Nations, from which there have been chosen the only those for "Industry, innovation and infrastructure" in the Europe (statistics available from [5]).

Monitoring the "SDG9 Build resilient infrastructure, promote inclusive and sustainable industrialization and foster innovation" in the European context focuses on two main dimensions: R\&D and innovation, and sustainable transport. As supported by the statistical data analysis of [5], "the European Union has progressed in $R \& D$ and innovation along several lines over the past few years, while some areas remained stagnant". In the same way, a mix of results can be observed on sustainable transport: "while the share of buses and trains in passenger transport has increased and $\mathrm{CO}_{2}$ emissions from cars declined, the share of rail and inland waterways in freight transport has not changed substantially" [5].

In the following there will be analysed the main indicators with related to the "Industry, innovation and infrastructure" by pointing out aspects related to the situation in Romania, in report with other European Member States situation.

\section{Research results and debates}

The statistical data in [5] shows that after a prolonged stagnation between 2000 and 2007, R\&D intensity has grown slowly. Between 2001 and 2016, R\&D intensity grew by an average of $0.9 \%$ per year. Growth was slightly slower in the short-term period between 2011 and 2016, at $0.6 \%$ per year on average. At the current pace of development, the Europe 2020 target of investing $3 \%$ of GDP in R\&D by 2020 will not be achieved. As seen in Fig. 1, the former Communist countries are at the bottom of the ranking, better positioning have been proofed by the Czech Republic and Hungary which expenditure are closer to the EU-28 value of $2 \%$ of GDP. In the case of Romania, the \% of GDP invested in R\&D has do not exceed 0.5 in 2011 and 2016.

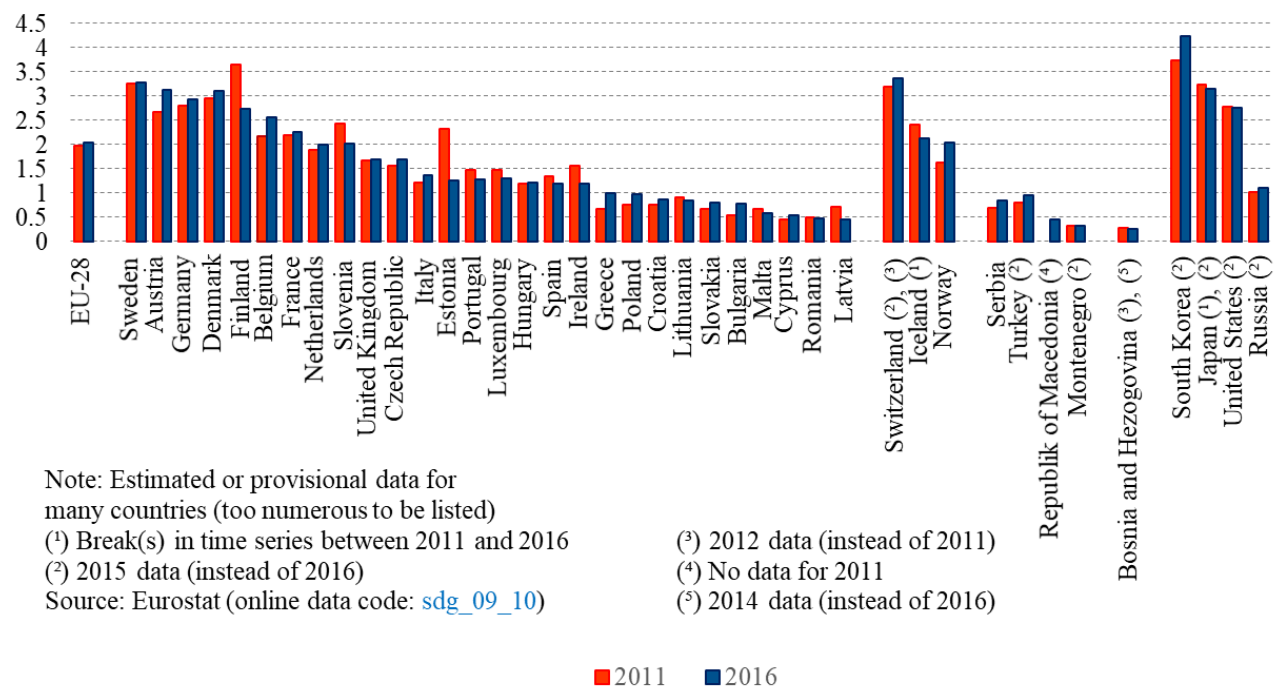

Fig. 1. Gross domestic expenditure, 2011 and 2016 (\% of GDP) [5]. 
In the case of the indicator "Employment in high- and medium-high technology manufacturing sectors and knowledge-intensive service sectors" the short-term tendency in showing an increasing trend. The Eurostat statistics were extended with data stem from the European Labour Force Survey (LFS). In generally, according to the [5] study, the share of employed people working either in high-and medium-high technology manufacturing or in knowledge-intensive service sectors has grown steadily since 2008 . In the short-term period since 2012 , the increase has amounted to $0.4 \%$ per year on average. Statistic data in the case of Romania demonstrate a low share of employed people working in R\&D sector, under the average of the EU-28 data available for the $\%$ of active population in full-time equivalents (Fig. 2); a small increasing, improvement of the share has been found in 2016 from 2011 related to Romania.

The situation is similar for the R\&D personnel indicator that measures the share of R\&D personnel broken down by the following institutional sectors: business enterprise, government, higher education and private non-profit (Fig. 3, [5]). Both in the long-term period between 2002 and 2016, and in the short-term period between 2011 and 2016, the share of R\&D personnel in the active population increased by $1.9 \%$ per year on average.

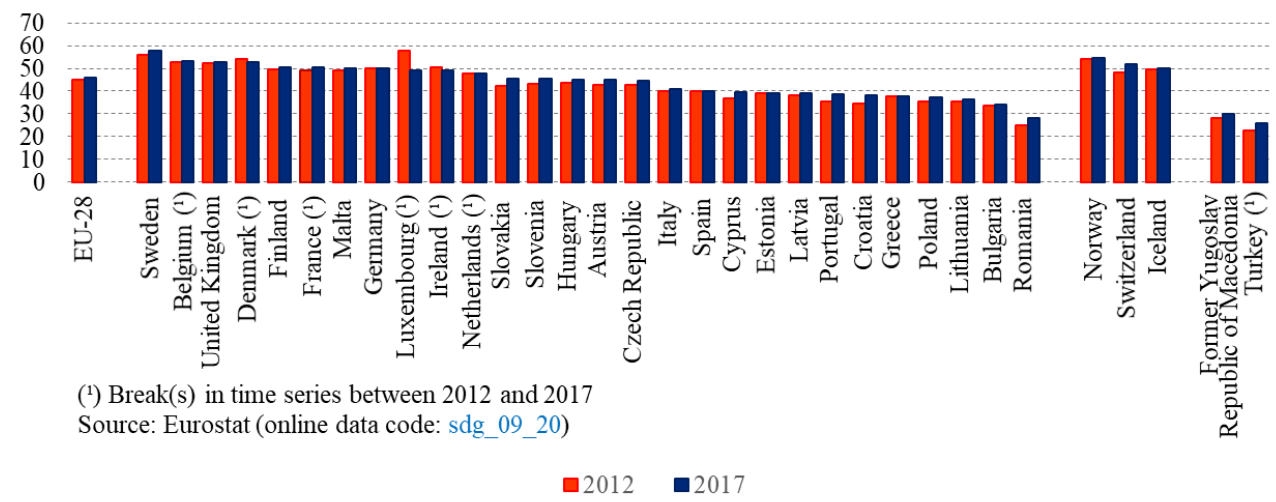

Fig. 2. Employment in high-and medium-high technology manufacturing sectors and knowledgeintensive service sectors, 2012 and 2017 (\% of total employment) [5].

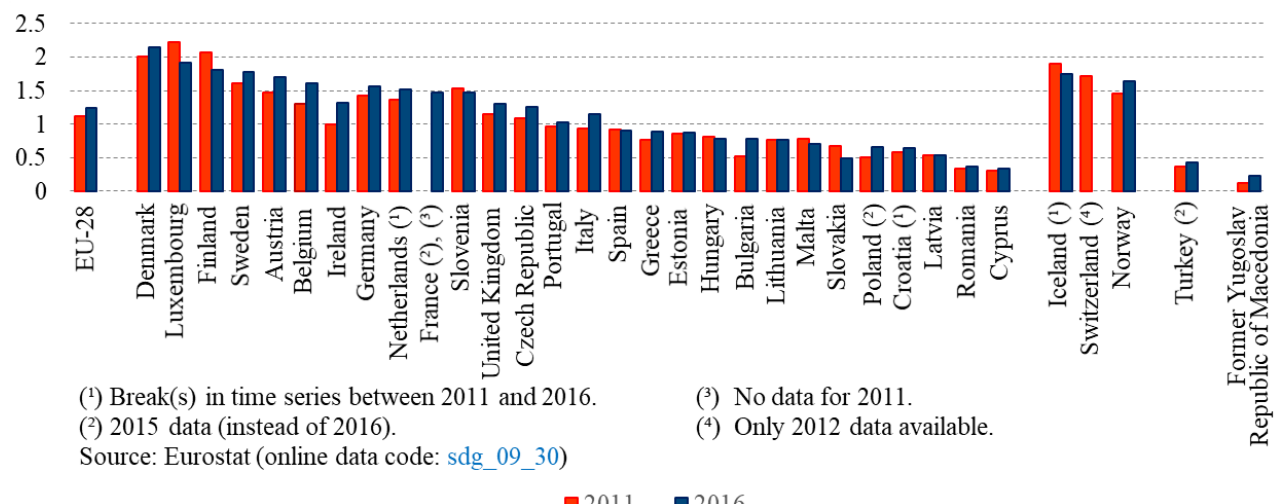

Fig. 3. R\&D personnel 2011 and 2016 (\% of active population in full-time equivalents) [5].

In the case of patent applications in the European Union the dynamics have been increased considerably prior to the economic crisis, and have stagnated ever since, with a slight decrease since 2015. The average increase for the long-term period from 2002 to 2017 amounts to $0.4 \%$ per year. In the short-term period since 2012, patent applications 
have fallen at an average annual rate of $0.8 \%$. As seen in Fig. 4 , the former Communist countries are at the bottom of the ranking, having register very low rates of patent application to the European Patent Office; Romania is in the queue of the class, together with Croatia and Bulgaria.

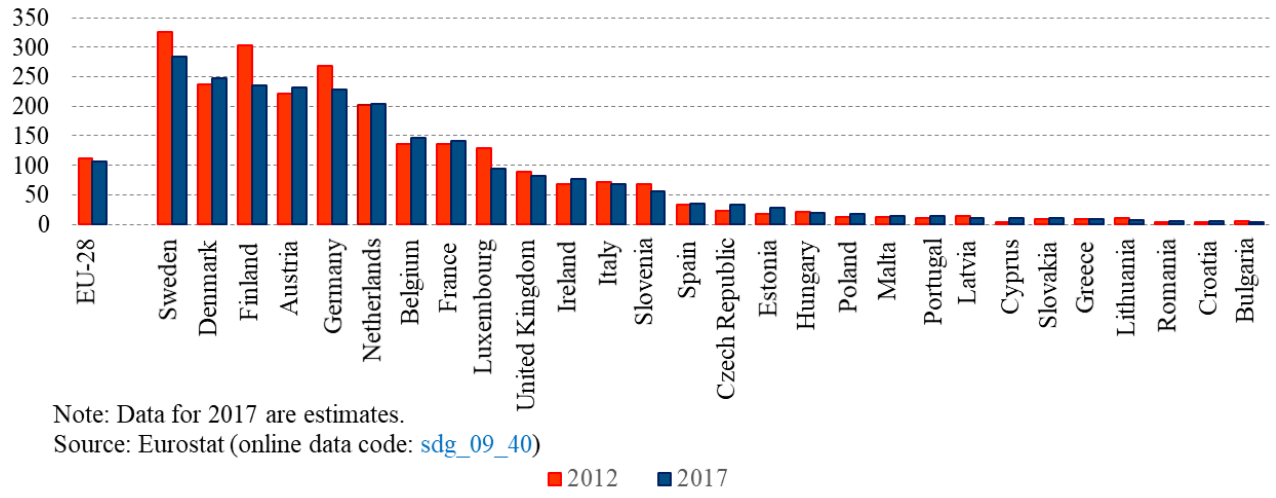

Fig. 4. Patent applications to the European Patent Office, 2012 and 2017 (number per million inhabitants) [5].

The statistical data at the European level shows that in the long-term period since 2001 the share of buses and trains in total passenger transport has fallen moderately, with an average annual decline of $0.1 \%$. In contrast, in the short-term period between 2011 and 2016 the share increased slightly, with an annual average growth rate of $0.4 \%$. The situation by countries is shown in Fig. 5. In the case of this indicator the analysis shows no differences between the West and the former Communist countries (Fig. 5) and that is because of the structural founds projects effectiveness that has been successful implemented to harmonize the local transport infrastructure in Europe.

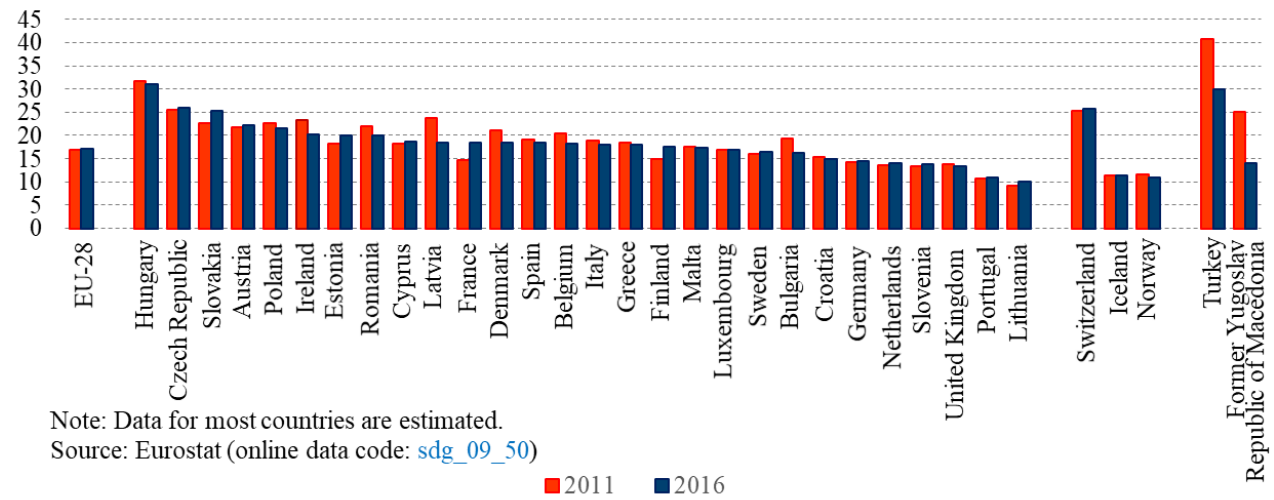

Fig. 5. Share of buses and trains in total passenger transport, EU-28, 2000-2016 (\% of total inland passenger-km) [5].

Like the modal split of passenger transport, the choice of transport mode for inland freight has not changed substantially since 2005 at the European level (EU-28). Between 2005 and 2016, the share of rail and inland waterways in total freight transport fell by $0.3 \%$ per year on average. In the short-term period since 2011, the decline has even been stronger, at an average of $1.1 \%$ per year. The statistical data per country level, Fig. 6, show a similar situation like in Fig. 5 , the former Communist countries being in the first half of the ranking. 


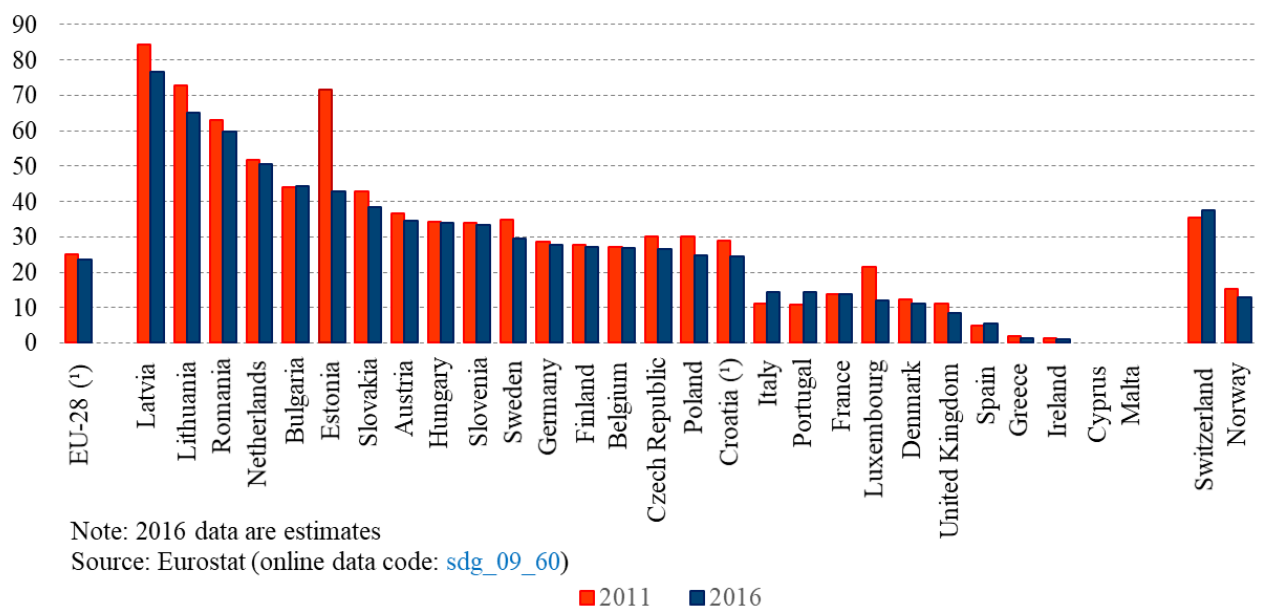

Fig. 6. Share of rail and inland waterways activity in total freight transport, 2011 and 2016 ( $\%$ of total inland freight tonne-km) [5].

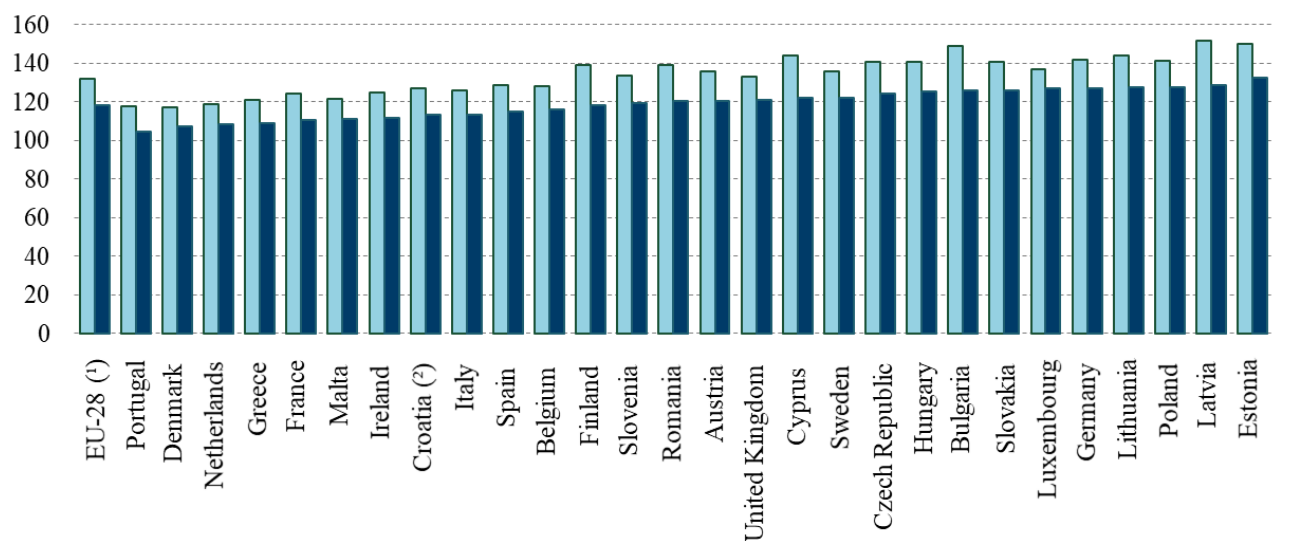

Note: 2017 data are provisional (all countries) $\quad$ (') 2012 data refer to EU-27 $\quad$ (2) 2013 data instead of 2012 Source: Eurostat (online data code: sdg_12_30)

\section{$\square 2012 \square 2017$}

Fig. 7. Average $\mathrm{CO}_{2}$ emissions per km from new passenger cars, by country, 2012 and $2017\left(\mathrm{~g} \mathrm{CO}_{2}\right.$ per $\mathrm{km})[5]$.

EU has made progress towards a cleaner car fleet over the past decade, although the trend has slowed down in recent years. Between 2007 and 2017, emissions fell by $2.9 \%$ per year on average, whereas in the short term from 2012 to 2017 the decline amounted to an average of only $2.2 \%$ per year. While the target for 2015 was met two years in advance, further progress seems necessary to reach the 2021 target. The situation statistics per countries (Fig. 7) shows average $\mathrm{CO}_{2}$ emissions per $\mathrm{km}$ from new passenger cars bigger in the case of the former Communist countries, which are situated in the second part of the ranking, from the point of view of this indicator; the values of the indicator for Romania (position in the middle of the ranking) show a slight overstatement of the EU-28 average. 


\section{CONCLUSIONS}

Monitoring SDG 9 in the European context focuses on two main dimensions: R\&D and innovation, and sustainable transport. The statistical data has proofed a clear difference between the achievements and results of the West and former Communist countries, which seems to be the main difficult of the general situation improvement.

In the context of the R\&D and innovation indicators, the following conclusions have been summarized:

- The selected indicators look at the monetary input into R\&D and innovation activities, the human resources employed in this sector, and the innovation output in terms of filed patents. The picture derived from available data for these indicators for the case of EU-28 and the West European countries since 2008 is characterized by stagnant trends of the inputs and outputs (R\&D intensity and patents), accompanied by a continuous increase in the human resources engaged in R\&D and innovation activities. The situation is stagnant and at low values of these indicators in the case of the former Communist countries and the situation is because of the skepticism and catastrophic approach on sustainable development, adopted by the population in the political context of each country;

- EU expenditure on R\&D in relation to GDP (R\&D intensity) has shown a modest growth during the past 15 years. After a prolonged stagnation between 2001 and 2007, R\&D intensity has increased slowly and has stabilized at slightly above $2.0 \%$ since 2012 , reaching $2.03 \%$ in 2016 . With a gap of about one percentage point, the EU thus remains far from its $3 \%$ target for 2020. The situation of the former Communist countries is linked with their expenditure for solving challenges related to poverty and differentiated access to education, culture (aspects related to the other SDGs goals). It seems that for those countries R\&D sector is still not of real priority, despite the EU policies over recent decades that has been to encourage increasing investment in R\&D;

- Overall, in many Member States the R\&D intensity emerged stronger from the economic crisis following stagnation in GDP and increased public funding for R\&D. Nevertheless, only Sweden and Austria recorded R\&D intensities above $3 \%$ of GDP in 2016;

- An analysis of R\&D expenditure by sector of performance shows that the two biggest spenders in 2016 remained the business enterprise sector $(65.0 \%)$ and the higher education sector (23.2\% of total R\&D expenditure in 2016). Despite its more modest share of $11.3 \%$ in 2016 , the government sector plays an important role, especially in the long-term stability of $R \& D$ expenditure and in fostering public-private initiatives. The size of the private non-profit sector is almost negligible, accounting for less than $1.0 \%$ of the total R\&D expenditure in 2016. The situation is similar in the case of the former Communist countries but with an average of $1 / 3$ of the total percent of R\&D expenditure, in 2016;

- As general observation, in the case of majority of EU Member States, R\&D expenditure in the business sector was the main determinant of a country's total R\&D intensity over the past decade;

- General statistics show that: $45.8 \%$ of employed people in the EU worked in high and medium high technology manufacturing or in knowledge intensive services in 2017; $1.2 \%$ of the active population in the EU worked in R\&D in 2016; 54649 patent applications from within the EU were submitted to the European Patent Office in 2017. In the case of the sustainable transport indicators, the following conclusions have been formulated:

- Sustainable transport is seen as an essential activity in the sustainable development strategies. Rethinking future mobility includes optimizing the use of all modes of 
transport, car sharing and integration between different modes of collective transport such as train, tram, metro, bus and taxi (multimodal transport);

- The shares of different transport modes in total passenger transport (modal split) have not changed substantially since 2000 , with passenger cars still accounting for almost 83 $\%$ of total land passenger transport in the Europe. The share of buses and trains has slightly fallen over the same period, from $17.3 \%$ in 2001 to $17.1 \%$ in 2016 . In the short term (since 2011), the share of these transport modes has increased moderately, by 0.3 percentage points;

- The largest increases in the share of cars in total passenger transport over the past five years were recorded in the youngest Member States (including former Communist countries), partly reflecting their economic growth and the increase in personal income. While cars remain the dominant mode for passenger transport across the EU, new car fleets are becoming cleaner: average carbon dioxide $\left(\mathrm{CO}_{2}\right)$ emissions from new passenger cars have fallen almost continuously since 2007 , reaching $118.5 \mathrm{~g} \mathrm{CO}_{2}$ per $\mathrm{km}$ in 2017.

- Like the modal split of passenger transport, the modal split of freight transport has not changed substantially since 2005. Despite the EU policy objective of shifting freight from road to rail, road continues to have by far the largest share of EU freight transport performance among the three inland transport modes analysed in this report (road, rail and inland waterways). Due to a marked increase in the share of road freight transport from 2015 to 2016, the share of rail and inland waterways in 2016 was lower than in most preceding years, accounting for $23.6 \%$ of total freight transport in the EU. Over the past five years, rail transport lost in importance (1.3 percentage points decrease from 2011 to 2016), reaching $17.4 \%$ in 2016 , while the share of inland waterways transport fluctuated between $6 \%$ and $7 \%$ over this period;

- Transport system depends on a country's broader logistical system and the availability of infrastructure for the various transport modes. Even though the modal split between different freight transport modes does not change substantially from year to year at the European level, at the country level considerable differences do exist. In 2016, four countries (Latvia, Lithuania, Romania and the Netherlands) had higher freight transport shares for rail and inland waterways than for road. Particularly high shares of rail transport were reported from the Baltic countries (Latvia, Lithuania and Estonia), which is essentially linked to the transport of Russian energy products to the Baltic ports. In the Netherlands, freight transport via inland waterways still has a very important role (modal split of $45.6 \%$ in 2016), almost matching the share of road (49.4 $\%$ in 2016);

- General statistics in this field show that: $17.1 \%$ of total inland passenger-km in the EU were covered by buses and trains in $2016 ; 23.6 \%$ of total freight transport in the EU was carried out via rail and inland waterways in 2016; 118.5 grams of $\mathrm{CO}_{2}$ per $\mathrm{km}$ were emitted by new passenger cars in the EU in 2017.

\section{References}

1. United Nation, Transforming our world: the 2030 Agenda for Sustainable Development, Available at : https://sustainabledevelopment.un.org/post2015/transformingourworld (Access on 10 of March, 2019)

2. M. Nilsson, D. Griggs, M. Visbeck, M., Policy: map the interactions between Sustainable Development Goals, Nature News, 534(7607), 320 (2016)

3. K. Szopik-Depczyńska, A. Kędzierska-Szczepaniak, K. Szczepaniak, K. Cheba, W. Gajda, G. Ioppolo, G., Innovation in sustainable development: an investigation of the EU context using 2030 agenda indicators, Land Use Policy, 79, pp.251-262 (2018) 
4. U. V. Nam, Transforming our world: The 2030 agenda for sustainable development, Division for Sustainable Development Goals, New York, NY, USA (2015)

5. Eurostat, Sustainable development in the European Union - Overview of progress towards the SDGs in an EU context, (2018), Available at :

https://ec.europa.eu/eurostat/documents/3217494/9237449/KS-01-18-656-EN-N.pdf/2b2a096b3bd6-4939-8ef3-11cfc14b9329 (Access on 10 of March, 2019)

6. A. M. McCright, R. E. Dunlap, S. T. Marquart-Pyatt, Political ideology and views about climate change in the European Union, Environmental Politics, 25(2), pp.338-358 (2016)

7. O. Edenhofer (Ed.), Climate change 2014: mitigation of climate change, (vol. 3, Cambridge University Press, 2015)

8. J. Urry, Climate change and society, In: Why the social sciences matter (pp. 45-59, Palgrave Macmillan, London, 2015).

9. IPCC, Climate Change 2007: Synthesis Report. Contribution of Working Groups I, II and III to the Fourth Assessment Report of the Intergovernmental Panel on Climate Change, Geneva: IPCC, Available at: https://www.ipcc.ch/report/ar4/syr/

10. IPCC, Climate Change 2014: Synthesis Report. Contribution of Working Groups I, II and III to the Fourth Assessment Report of the Intergovernmental Panel on Climate Change, Geneva: IPCC, Available at: https://www.ipcc.ch/site/assets/uploads/2018/05/SYR_AR5_FINAL_full_wcover.pdf

11. IPCC, AR6 Climate Change 2021: Impacts, Adaptation and Vulnerability, Geneva: IPCC, Available at: https://www.ipcc.ch/report/sixth-assessment-report-working-group-ii/

12. R. Plummer, Doom, gloom, or boom? Perceptions of climate change among Canadian winegrowers, International Journal of Wine Research, 11, pp.1-11 (2019)

13. M. F. Eskjær, The Climate Catastrophe as Blockbuster. Akademisk kvarter / Academic Quarter, pp.366-349 (2019)

14. P. Chaisty, S. Whitefield, Attitudes towards the environment: are post-communist societies (still) different? Environmental Politics, 24(4), pp.598-616 (2015)

15. D. Reckien, M. Salvia, O. Heidrich, J. M. Church, F. Pietrapertosa, S. De Gregorio-Hurtado, ... H. Orru, How are cities planning to respond to climate change? Assessment of local climate plans from 885 cities in the EU-28, Journal of Cleaner Production, 191, pp.207-219 (2018)

16. M. Agovino, M. Casaccia, M. Ciommi, M. Ferrara, K. Marchesano, Agriculture, climate change and sustainability: The case of EU-28, Ecological Indicators (2018) 